\title{
Production of insulin resistance by hyperinsulinaemia in man
}

\author{
R. A. Rizza, L.J. Mandarino, J. Genest, B. A. Baker and J. E. Gerich \\ Endocrine Research Unit, Departments of Medicine and Physiology, Mayo Medical School and Mayo Clinic, Rochester, Minnesota, USA
}

\begin{abstract}
Summary. It has been proposed that hyperinsulinaemia may cause or exacerbate insulin resistance. The present studies were undertaken to test this hypothesis in man. Glucose utilization, glucose production, and overall glucose metabolism at submaximally and maximally effective plasma insulin concentrations ( $\sim 80$ and $\sim 1700 \mathrm{mU} / 1$ ), and monocyte and adipocyte insulin binding were measured in normal volunteers on two occasions: once after $40 \mathrm{~h}$ of hyperinsulinaemia (25-35 mU/1) produced by infusion of insulin and once after infusion of saline $(75 \mathrm{mmol} / 1$; plasma insulin $\sim 10 \mathrm{mU} / \mathrm{l})$. After $40 \mathrm{~h}$ of hyperinsulinaemia, glucose utilization and overall glucose metabolism at submaximally and maximally effective plasma insulin concentrations were both slightly, but significantly, reduced compared with values observed after the infu-
\end{abstract}

sion of saline $(p<0.05)$, whereas glucose production rates were unaffected. Monocyte and adipocyte binding were also unaffected. These results indicate that hyperinsulinaemia of the magnitude observed in insulin resistant states, such as obesity, can produce insulin resistance in man. Assuming that human insulin sensitive tissues possess spare insulin receptors and that monocyte and adipocyte insulin binding accurately reflect insulin binding in insulin-sensitive tissues, the decreased maximal responses to insulin and the lack of change in insulin binding suggest that this insulin resistance occurred at a post-binding site.

Key words: Hyperinsulinaemia, insulin resistance, glucose utilization.
The relationship between plasma insulin concentration and insulin resistance in man is unclear. Insulin resistance is usually associated with hyperinsulinaemia when there is sufficient pancreatic $\beta$-cell reserve [1,2]. It is generally thought that insulin secretion increases in these conditions to compensate for the decrease in insulin action. On the other hand, there is evidence that increased insulin concentrations can down-regulate insulin receptors [3, 4] and in animals, under certain experimental conditions, may impair intracellular responses subsequent to insulin receptor binding $[5,6]$. It has been inferred from the above considerations that hyperinsulinaemia may play an important role in the production or exacerbation of insulin resistance in man $[2,3,8]$.

To date, there has been no direct demonstration that hyperinsulinaemia can produce insulin resistance in vivo in man. The correlations observed between plasma insulin concentrations and insulin resistance in conditions such as obesity $[7,9,10]$ may merely reflect a compensatory increase in insulin secretion rather than hyperinsulinaemia being the cause of insulin resistance. In fact, in some studies, when animal tissues had been previously exposed in vivo or in vitro to increased con- centrations of insulin, subsequent tissue responses to insulin have been increased rather than decreased [11,12]. The present studies were undertaken, therefore, to test the hypothesis that hyperinsulinaemia, similar to that observed in insulin-resistant states such as obesity, can cause insulin resistance in man and, if so, to determine whether this impairment in insulin action occurred at a receptor or a post-binding site.

\section{Subjects and methods}

\section{Subjects}

Following approval by the Institutional Ethical Committee, informed written consent was obtained from 12 non-obese male volunteers (aged $29 \pm 3$ years, body mass index $23 \pm 1 \mathrm{~kg} / \mathrm{m}^{2}$ ) who were within $10 \%$ of their ideal body weight and had no family history of diabetes mellitus. Subjects were admitted twice to the Mayo Clinic Research Center, and were infused with either $\mathrm{NaCl}(75 \mathrm{mmol} / \mathrm{l})$ or with crystalline pork insulin (Eli Lilly, Indianapolis, Indiana, USA; $0.4 \mathrm{mU}$. $\mathrm{kg}^{-1} \cdot \min ^{-1}$ made up in $1 \%$ human serum albumin) for $40 \mathrm{~h}$ using a portable infusion pump (Travenol Laboratories, Deerfield, Illinois, USA). During the insulin infusion, glucose $(20 \mathrm{~g} / 100 \mathrm{ml})$ was also infused at a rate of approximately $16 \mu \mathrm{mol} \cdot \mathrm{kg}^{-1} \cdot \mathrm{min}^{-1}$ to maintain plasma glucose concentrations within the euglycaemic range. The in- 

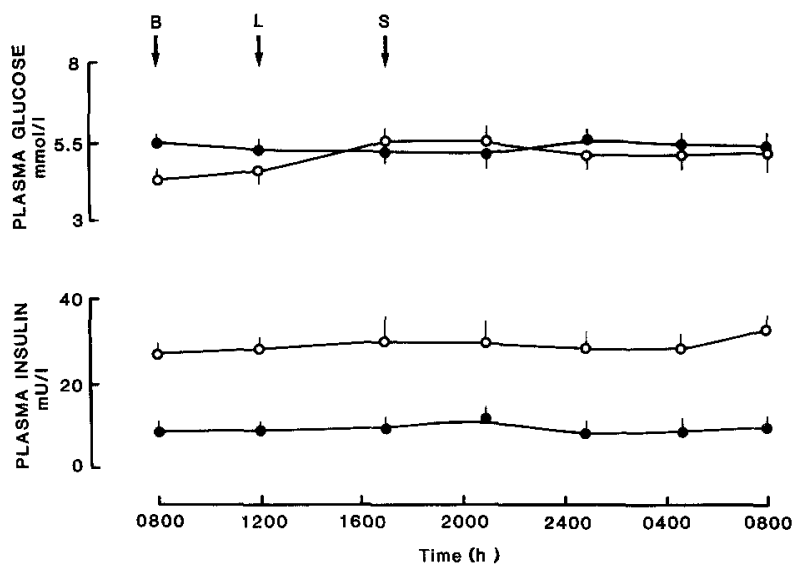

Fig. 1. Pre-prandial and fasting plasma glucose and insulin concentrations during infusion of saline $(2.5 \mathrm{mmol} / \mathrm{min})$ or insulin $(0.4 \mathrm{mU}$. $\mathrm{kg}^{-1} \cdot \min ^{-1}$ ) during the $24-\mathrm{h}$ period prior to the insulin dose-response study. B, L, and $\mathrm{S}$ indicate times at which breakfast, lunch, and supper were digested. Saline: $\longrightarrow$, insulin: $\bigcirc-\mathrm{O}$, mean $\pm \mathrm{SEM}, n=7$
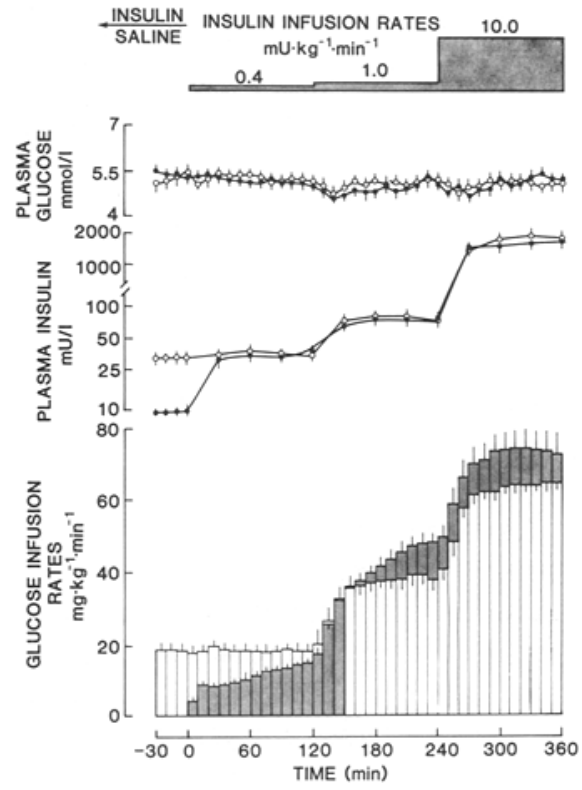

Fig. 2. Plasma glucose and insulin concentrations and glucose infusion rates necessary to maintain euglycaemia during the initial 120 -min equilibration period and the subsequent dose-response study during which insulin was infused at submaximal $\left(1.0 \mathrm{mU} \cdot \mathrm{kg}^{-1}\right.$. $\left.\mathrm{min}^{-1}\right)$ and maximal $\left(10 \mathrm{mU} \cdot \mathrm{kg}^{-1} \cdot \mathrm{min}^{-1}\right)$ effective rates. Saline: - and shaded bars, insulin: $\mathrm{O}-\mathrm{O}$ and open bars, mean \pm SEM, $n=7$

sulin and saline infusions were given in random order and separated by at least one week (median 7, range 7-60 days). The subjects remained ambulatory and ingested identical meals (totaling $30 \mathrm{Kcal} / \mathrm{kg}$ as $40 \%$ carbohydrate, $35 \%$ fat, $15 \%$ protein) at 0800,1200 , and $1700 \mathrm{~h}$ on both occasions. Following both infusions, insulin action and monocyte binding were assessed in seven subjects and adipocyte insulin binding in five additional subjects.

\section{Assessment of insulin action on glucose production and utilization}

Towards the end of the insulin and saline infusions $(0700 \mathrm{~h})$, the subjects were placed at bed rest and maintained supine thereafter. A primed $(22 \mu \mathrm{Ci} / \mathrm{min})$ continuous $(0.22 \mu \mathrm{Ci} / \mathrm{min})$ infusion of $\left[3-{ }^{3} \mathrm{H}\right]$ glucose (New England Nuclear, Boston, Massachusetts, USA) was begun, and a 4-h equilibration period was allowed before the initiation of dose-response experiments.

Since several hours are required for the response to an increment in plasma insulin to reach a steady-state $[13,14]$ and in order to provide identical increments in plasma insulin during the dose-response studies under both experimental conditions, subjects were infused with insulin in the saline infusion experiments for $2 \mathrm{~h}$ at a rate $\left(0.4 \mathrm{mU} \cdot \mathrm{kg}^{-1} \cdot \mathrm{min}^{-1}\right)$ equal to the rate at which insulin had been infused for $40 \mathrm{~h}$. Thereafter, in both experiments, insulin was infused sequentially as described previously [14] at 1.0 and $10.0 \mathrm{mU} \cdot \mathrm{kg}^{-1}$. min $^{-1}$ which stimulates glucose disposal submaximally and maximally, respectively $[7,14,15]$; arterialized venous plasma glucose concentrations were clamped at approximately $5.3 \mathrm{mmol} / 1$ [14].

Rates of total glucose appearance (endogenously produced and exogenously infused) and glucose utilization were determined isotopically using the equations of DeBodo et al. [16]. Endogenous glucose production rate was calculated by subtracting the exogenous glucose infusion rate from the isotopically determined total glucose appearance rate. The amount of glucose infused was calculated at 10-min intervals throughout all experiments. The glucose infusion rates and the rates of glucose production and utilization over the last $40 \mathrm{~min}$ of each $120-\mathrm{min}$ insulin infusion were used for calculation of responses to insulin $[7,14]$.

\section{Monocyte receptor studies}

At the end of the saline and 40-h insulin infusions, mononuclear cells were isolated from heparinized blood by a modification of the FicollHypaque technique [17] and were counted with a Coulter counter (Coulter Electronics, Hialeah, Florida, USA). The proportion of monocytes in each mononuclear cell preparation was determined by non-specific esterase staining [18]. Insulin binding was determined by the method of De Meyts [19].

\section{Adipocyte isolation and binding}

Adipocytes were isolated by a modification [20] of the collagenase digestion method of Rodbell [21]. Approximately $6 \mathrm{~g}$ of subcutaneous adipose tissue was obtained from the left or right lower abdominal quadrant from the centre of an area anaesthetized locally in a squarefield fashion [7]. The tissue was washed in warm $\left(37^{\circ} \mathrm{C}\right)$ saline and $1-\mathrm{g}$ portions, which had been cut into $5 \times 5 \mathrm{~mm}$ pieces, were placed into polyethylene vessels. Each vessel contained $6 \mathrm{ml}$ Krebs-Ringer-bicarbonate buffer in mmol/1: $\mathrm{NaCl}, 116 ; \mathrm{NaHCO}_{3}, 29 ; \mathrm{KCL}, 4.4$; $\mathrm{MgSO}_{4}, 1.2 ; \mathrm{CaCl}_{2} .2 \mathrm{H}_{2} \mathrm{O}, 1.2 ; \mathrm{pH} 7.6$ at $37{ }^{\circ} \mathrm{C}$ after gassing with $95 \%$ $\mathrm{O}_{2}: 5 \% \mathrm{CO}_{2}$, containing $3.5 \%$ bovine plasma albumin (Armour Pharmaceuticals, Kankakee, Illinois, USA), $5 \mathrm{mmol} / 1$ glucose, $3 \mathrm{mg}$ collagenase (Worthing Biochemicals, Millipore Corporation, Freehold, New Jersey, USA). After shaking for $1 \mathrm{~h}$ at $37^{\circ} \mathrm{C}$, the digested tissue was passed first through a $1000-\mu \mathrm{m}$ and then through a $250-\mu \mathrm{m}$ nylon mesh. Care was taken to maintain the adipocytes at $37^{\circ} \mathrm{C}$ at all times. The cells were then centrifuged at $100 \mathrm{~g}$ for $1 \mathrm{~min}$ in $16 \times 100 \mathrm{~mm}$ polyethylene tubes (AS Nunc, Roskilde, Denmark), the infranatant removed, and an equal volume of buffer at $37^{\circ} \mathrm{C}$ added. After resuspension by gentle inversion, the cells were recentrifuged and washed twice in the same manner into a Hepes buffer in mmol/l: Hepes-2-hydroxyethylpiperazine- $\mathrm{N}^{\prime}$-2-ethane sulphonic acid, 10; $\left.\mathrm{NaCl}, 135 ; \mathrm{KCl}, 4.8 ; \mathrm{CaCl}_{2} \cdot \mathrm{H}_{2} \mathrm{O}, 2.5 ; \mathrm{MgSO}_{4}, 1.7 ; \mathrm{NaH}_{2} \mathrm{PO}_{4}, 1.0\right]$, $\mathrm{pH} 7.6$ at $37{ }^{\circ} \mathrm{C}$ after gassing, containing $5 \%$ bovine plasma albumin, bacitracin $(0.5 \mathrm{mg} / \mathrm{ml}$; Sigma, St. Louis, Missouri, USA) and glucose $(5 \mathrm{mmol} / \mathrm{l})$. Following final resuspension of the cells, an aliquot was fixed in $1 \%$ osmium tetroxide in collidine- $\mathrm{HCl}$ buffer for cell counting and size analysis by a modification of the method of Hirsch and Gallian [22].

Adipocyte insulin binding was determined by a modification of the method of Pedersen et al. [20]. Isolated adipocytes (approximately $5 \times 10^{5} / \mathrm{ml}$ ) were incubated in triplicate in a final volume of $0.5 \mathrm{ml}$ Hepes buffer, containing $0.2 \mathrm{ng} / \mathrm{ml}$ of $\left.{ }^{125} \mathrm{I}\right]$-insulin bound in the pres- 
ence of $100,000 \mathrm{ng} / \mathrm{ml}$ unlabelled insulin and was subtracted from all other values. Incubations were carried out by slow shaking at $37{ }^{\circ} \mathrm{C}$ for $1 \mathrm{~h}$. Following incubation, duplicate aliquots $(0.2 \mathrm{ml})$ were removed from each tube and centrifuged for $1 \mathrm{~min}$ at $2500 \mathrm{~g}$ through $0.2 \mathrm{ml}$ silicone oil (Silwet 722, Union Carbide, Danbury, Connecticut, USA) in a microcentrifuge (Beckman, Arlington Heights, Illinois, USA). The portion of the centrifuge tube containing the cells, which float on the oil, was excised and its radioactivity was counted using a gamma counter (Nuclear, Chicago, Illinois, USA). Results were expressed as insulin bound specifically per $2 \times 10^{5}$ adipocytes. Incubations carried out in this manner result in a steady-state binding of $30-45 \mathrm{~min}$ which is maintained for at last $150 \mathrm{~min}$.

\section{Analytical techniques and statistical analysis}

All glucose and insulin concentrations were determined on arterialized-venous samples. Blood for insulin [23] and glucose determinations were obtained before meais at $2100,0100,0500$, and $0900 \mathrm{~h}$ over the final 24-h period before the dose-response studies. During the dose response studies, blood samples were collected at 10-min intervals for glucose and glucose specific activity and at 30-min intervals for insulin as described previously [14]. Data are given as meant SEM. Statistical analyses were performed using two-tailed paired Student's t-tests. A $p$ value of $<0.05$ was considered to be statistically significant.

\section{Results}

\section{Plasma glucose and insulin concentrations}

Plasma glucose and insulin concentrations over the 24-h period before the dose-response studies, during which either insulin or saline was infused, are shown in Figure 1. Plasma insulin concentrations during the insu-

Table 1. Effect of antecedent hyperinsulinaemia on stimulation of glucose utilization and suppression of glucose production by insulin

\begin{tabular}{cll}
\hline & \multicolumn{2}{l}{ Insulin infusion rates } \\
\cline { 2 - 3 } & $\begin{array}{l}\left(1 \mathrm{mU} \cdot \mathrm{kg}^{-1} \cdot\right. \\
\left.\mathrm{min}^{-1}\right)\end{array}$ & $\begin{array}{l}\left(10 \mathrm{mU} \cdot \mathrm{kg}^{-1} \cdot\right. \\
\left.\mathrm{min}^{-1}\right)\end{array}$ \\
\hline $\begin{array}{ll}\text { Glucose utilization }(n=7) \\
\left(\text { mmol } \cdot \mathrm{kg}^{-1} \cdot \mathrm{min}^{-1}\right)\end{array}$ & & \\
$\quad$ Saline & & \\
Hyperinsulinaemia & $34 \pm 3$ & $68 \pm 5$ \\
& $p<0.01$ & $p< \pm 3$ \\
Glucose production $(n=7)$ & & \\
(mmol $\cdot \mathrm{kg}^{-1} \cdot$ min $\left.^{-1}\right)$ & & \\
Saline & $0.0 \pm 2$ & $0.0 \pm 3$ \\
Hyperinsulinaemia & $2 \pm 1$ & $2 \pm 1$ \\
& $p<0.50$ & $p<0.80$ \\
\hline
\end{tabular}

Results expressed as mean \pm SEM lin infusion $(26 \pm 2 \mathrm{mU} / 1)$ were significantly greater than those during the saline infusion $(9 \pm 1 \mathrm{mU} / 1, p<$ 0.001 ). However, plasma glucose concentrations during the insulin and saline infusions were comparable $(5.1 \pm 0.2$ and $5.4 \pm 0.1 \mathrm{mmol} / \mathrm{l}$, respectively).

Plasma glucose and insulin concentrations during the equilibration period following the saline infusions and the subsequent dose-response studies are shown in Figure 2. During the 2-h equilibration period following the saline infusion, subjects were infused with insulin at the same rate as that used during the prolonged insulin infusions $\left(0.4 \mathrm{mU} \cdot \mathrm{kg}^{-1} \cdot \mathrm{min}^{-1}\right)$; the plasma insulin and glucose concentrations $(34 \pm 3 \mathrm{mU} / 1$ and $5.3 \pm$ $0.1 \mathrm{mmol} / \mathrm{l}$ ) during this period were comparable to those during the same interval of the hyperinsulinaemia experiment $(36 \pm 2 \mathrm{mU} / 1$ and $5.4 \pm 0.1 \mathrm{mmol} / \mathrm{l})$. During the dose-response studies, plasma glucose concentrations were clamped at $5.3 \pm 0.1 \mathrm{mmol} / 1$ (coefficient of variation $4.4 \pm 0.3 \%$ ) during the hyperinsulinaemia experiment and at $5.2 \pm 0.1 \mathrm{mmol} / \mathrm{l}$ (coefficient of variation $5.1 \pm 0.3 \%$ ) during the saline experiment. Plasma insulin concentrations reached comparable plateau within $30 \mathrm{~min}$ during the $1.0 \mathrm{mU} \cdot \mathrm{kg}^{-1} \mathrm{~min}^{-1}(79 \pm 5$ versus $81 \pm 8 \mathrm{mU} / \mathrm{l}$ ) and during the $10 \mathrm{mU} \cdot \mathrm{kg}^{-1} \cdot \mathrm{min}^{-1}$ $(1779 \pm 135$ versus $1630 \pm 145 \mathrm{mU} / 1)$ insulin infusions in the hyperinsulinaemia and saline experiments, respectively.

\section{Rates of glucose infusion, utilization and production during the dose-response studies}

Glucose infusion rates necessary to maintain euglycaemia during infusions of insulin are equal to the sum of the increase in glucose utilization and the decrease in glucose production induced by insulin, and can thus be used as a measure for the overall effect of insulin on glucose metabolism. The steady-state glucose infusion rates necessary to maintain euglycaemia during both the submaximally $\left(1.0 \mathrm{mU} \cdot \mathrm{kg}^{-1} \cdot \mathrm{min}^{-1}\right)$ and maximally $\left(10 \mathrm{U} \cdot \mathrm{kg}^{-1} \cdot \mathrm{min}^{-1}\right)$ effective insulin infusions were significantly less following $40 \mathrm{~h}$ of antecedent hyperinsulinaemia $\left(37 \pm 3\right.$ and $\left.60 \pm 2 \mu \mathrm{mol} \cdot \mathrm{kg}^{-1} \cdot \mathrm{min}^{-1}\right)$ than those following the saline infusion $(44 \pm 3$ and $68 \pm$ $\left.5 \mu \mathrm{mol} \cdot \mathrm{kg}^{-1} \cdot \mathrm{min}^{-1} ; p<0.05\right)$. Glucose utilization following antecedent hyperinsulinaemia was also significantly less at both insulin infusion rates, whereas glucose production was comparably suppressed in the saline and hyperinsulinaemia experiments (Table 1).

Table 2. Effect of antecedent hyperinsulinaemia on adipocyte insulin binding

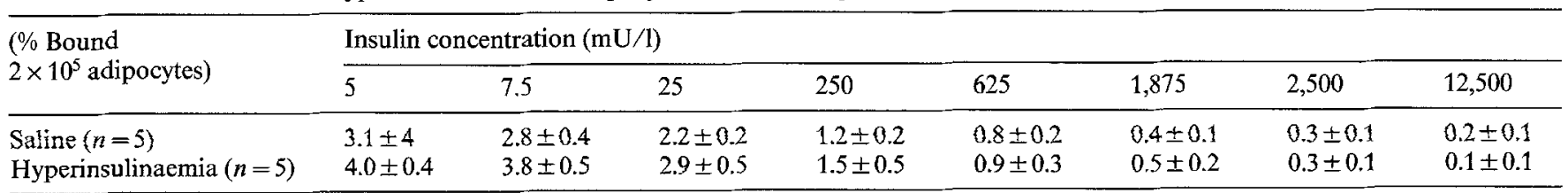

Results expressed as mean \pm SEM 


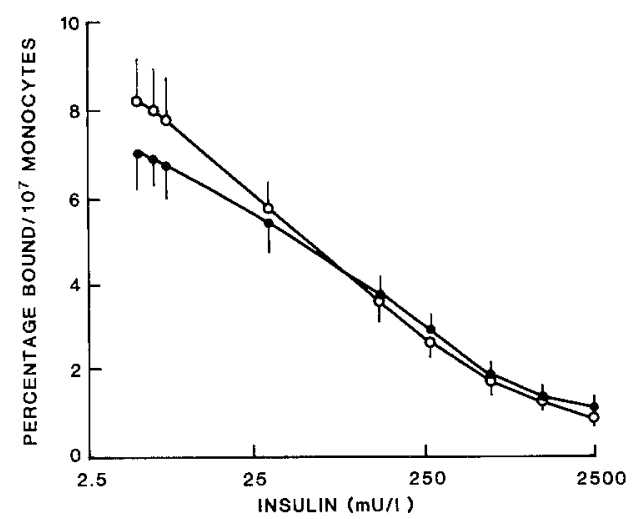

Fig.3. Monocyte insulin binding after insulin or saline infusion. Saline: $\longrightarrow$, insulin: $\bigcirc-0$, mean \pm SEM, $n=7$

\section{Monocyte insulin binding}

Monocyte insulin binding after $40 \mathrm{~h}$ or hyperinsulinaemia did not differ significantly from insulin binding after $40 \mathrm{~h}$ of saline (Fig. 3).

\section{Adipocyte insulin binding}

Plasma glucose concentrations over the 24 -h period before the adipocyte biopsy were equivalent during the insulin $(5.2 \pm 0.2 \mathrm{mmol} / \mathrm{l})$ and saline infusions (5.2 \pm $0.1 \mathrm{mmol} / 1)$. Plasma insulin concentrations were significantly greater during the insulin infusion $(35 \pm 5 \mathrm{mU} / \mathrm{l})$ than during the saline infusion $(8 \pm 1 \mathrm{mU} / 1 ; p<0.05)$. Adipocyte insulin binding after $40 \mathrm{~h}$ of insulin infusion was not significantly different from insulin binding after the saline infusion at any insulin concentrations studied.

\section{Discussion}

The present studies demonstrate that sustained hyperinsulinaemia can cause insulin resistance in man. Following 40-h infusion of insulin which increased plasma insulin concentrations to levels similar to those observed in insulin-resistant conditions, such as obesity (25$35 \mathrm{mU} / 1$ ) [1, 7], insulin-stimulated glucose utilization was slightly but significantly decreased at both submaximally and maximally effective plasma insulin concentrations. Monocyte and adipocyte insulin binding were unchanged. If one assumes that insulin sensitive tissues, such as muscle, possess spare insulin receptors and that monocyte and adipocyte insulin binding reflects insulin binding in those tissues, then the decreased maximal response to insulin and the lack of change in insulin binding both suggest that the impaired insulin action induced by the hyperinsulinaemia occurred at a postbinding site.

Previous studies in animals examining the effects of antecedent increases in insulin concentrations or the subsequent stimulation by insulin of rat adipocyte glu- cose metabolism have yielded contradictory results $[5$, $12,24,27]$. Incubation [5], injection [12, 25] or infusion $[26,27]$ of insulin in rats has been reported to decrease $[5,24,25]$, increase $[12,26,27]$ or not to influence [5] adipocyte response to insulin. Extrapolation of these results to man is further confounded by the fact that muscle not adipose tissue is primarily responsible for insulin-stimulated glucose utilization in vivo [28]. In the rat, differences between adipocyte and muscle response to chronic hyperinsulinaemia have been reported in abstract form by Horton et al. [27], with a decrease in insulin-stimulated glucose metabolism being observed in the former but not the latter tissue. In contrast, the current studies indicate that in man, at least over the shortterm, mild hyperinsulinaemia $(25-35 \mathrm{mU} / 1)$ decreased insulin-stimulated glucose disposal implying decreased muscle glucose metabolism. Whether comparable changes occurred in human adipocyte glucose metabolism awaits further study.

The hyperinsulinaemia-induced decrease in insulin action observed in the present study, although uniformly observed and statistically significant, was relatively small $\left(5.5 \mu \mathrm{mol} \cdot \mathrm{kg}^{-1} \cdot \mathrm{min}^{-1}\right)$. While it is possible that antecedent hyperinsulinaemia may not have a major regulatory influence on insulin action in man, several aspects of the current experimental design utilized could have led to an underestimation of the effect of hyperinsulinaemia, including (a) inhibition of endogenous insulin release by the exogenous insulin infusion [29] thereby minimizing differences in portal insulin concentrations during the antecedent saline and insulin infusions, (b) lack of steady-state conditions during the insulin dose-response studies following the antecedent saline infusion (i.e. a priming effect had occurred during the antecedent insulin infusion) $[13,14]$, (c) the degree of hyperinsulinaemia was mild, and probably most importantly, (d) the duration was brief $(40 \mathrm{~h})$ relative to that present in chronic hyperinsulinaemic states. Thus, although the current experiments demonstrate that hyperinsulinaemia can impair insulin action, due to the small magnitude of this effect, the biological significance of this phenomenon remains to be determined.

The lack of change in insulin-induced suppression of hepatic glucose production following sustained hyperinsulinaemia should be interpreted with caution. Although maximal suppression of hepatic glucose production by insulin was unaltered following $40 \mathrm{~h}$ of hyperinsulinaemia, the concentrations of insulin achieved during the 1.0 and $10.0 \mathrm{mU} \cdot \mathrm{kg}^{-1} \cdot \mathrm{min}^{-1}$ insulin infusion rates normally produced near-maximal suppression of hepatic glucose production [14]. Thus, a decreased response to submaximal insulin concentrations (i.e., decreased hepatic sensitivity to insulin) may have been missed. The observation that the glucose production rates during the $0.4 \mathrm{mU} \cdot \mathrm{kg}^{-1} \cdot \mathrm{min}^{-1}$ priming insulin infusions were significantly greater following hyperinsulinaemia $\left(5.5 \pm 1.1 \mu \mathrm{mol} \cdot \mathrm{kg}^{-1} \cdot \mathrm{min}^{-1}\right)$ than following saline $\left(3.9 \pm 1.1 \mu \mathrm{mol} \cdot \mathrm{kg}^{-1} \cdot \mathrm{min}^{-1}, p<0.05\right)$ 
suggests that this may have been the case. Our results, therefore, do not exclude the possibility that hyperinsulinaemia also can produce hepatic resistance to insulin.

Neither monocyte nor adipocyte insulin binding were decreased after $40 \mathrm{~h}$ of sustained hyperinsulinaemia averaging approximately $25-35 \mathrm{mU} / 1$. Other investigators $[14,30]$, using insulin concentrations severalfold greater than those employed in the current study, have reported that hyperinsulinaemia can decrease monocyte insulin binding. Since insulin-induced downregulation of insulin binding appears to be both timeand concentration-dependent [31], we cannot exclude the possibility that hyperinsulinaemia at the concentrations we employed may have eventually produced a decrease in binding. The recent report [8] that adipocyte binding is decreased in patients with Type 1 (insulin-dependent) diabetes who are chronically hyperinsulinaemic due to exogenous insulin therapy supports this possibility. Nevertheless, the current studies indicate that modest sustained basal hyperinsulinaemia, under the present experimental conditions, does not cause downregulation of monocyte and erythrocyte insulin receptor binding.

Assuming that human muscles possess spare insulin receptors, as has been demonstrated in animals $[32,33]$ the decreased maximal response to insulin following antecedent hyperinsulinaemia suggests a post-binding defect in insulin action. This conclusion is supported by the lack of change in either monocyte or adipocyte binding following hyperinsulinaemia (although the latter was only measured in five of the 12 subjects and, therefore, may not reflect the binding in the other seven). Our conclusion is also consistent with the studies of Marshall and Olefsky [5] and Mandarino et al. [34] in which pre-incubation of rat adipocytes with insulin [5] or 6-h infusions of insulin in normal human volunteers [34] produced a post-receptor defect in the stimulation of adipocyte glucose transport by insulin.

The mechanism responsible for the hyperinsulinaemic impairment of insulin action is unknown. In the present studies, as well as in previous animal studies [12, $24,26]$, additional calories were provided as glucose during the induction of hyperinsulinaemia to prevent hypoglycaemia. Thus, it is not possible to determine whether the observed decrease in insulin action was due to a direct effect of insulin at an early post-binding step or an indirect effect of insulin resulting from a biological action of insulin (i.e. stimulation of glucose uptake and metabolism). Hyperinsulinaemia may also impair insulin action by altering the plasma concentrations of flux of the numerous other substrates and hormones. Alterations in plasma catecholamine concentrations may be an important example of the latter.

The present studies, in conjunction with previous reports $[7,9,35]$, emphasize the complexity of the interactions between hyperinsulinaemia, insulin receptor binding, post-binding events, and the resultant biological response to insulin. In view of these complexities, one may not necessarily be able to deduce the sequence of events leading to insulin resistance when hyperinsulinaemia, decreased insulin receptor binding, and a postreceptor defect in insulin action are all present simultaneously.

In conclusion, the present studies demonstrate that hyperinsulinaemia produced by infusion of insulin can cause insulin resistance in man and that this decrease in insulin action probably occurs at a post-receptor site. Although the changes in the current study are small, the implication is that hyperinsulinaemia, whether due to increased secretion, decreased clearance (e.g., hepatic or renal disease), or exogenous insulin administration (Type 1 diabetes), may also impair insulin action and thus be involved in the pathogenesis of insulin resistance in a variety of disease states.

Acknowledgements. Supported in part by grants from the USPHS (AM-29953, AM-20411, AM-07352, RR-00585), the Minnesota Affiliate of the American Diabetes Association, the Mayo Foundation, and Mr. and Mrs. B. Rappaport. We thank T. Lund, J. King, L. Hall, R. Westland, K.Greene, D. Nashond, S.LeBlanc for their excellent technical assistance, and K. Welch and P. Voelker for their superb editorial help. L. Mandarino was the recipient of the Rosalyn Yallow Research and Career Development Award from the American Diabetes Association. Presented in part at the Annual Meeting of the American Society for Clinical Investigation, 8-10 May, 1982.

\section{References}

1. Karam J, Grodsky G, Forsham P (1963) Excessive insulin response to glucose in obese subjects as measured by immunochemical assay. Diabetes 12: 196-204

2. Olefsky J (1976) The insulin receptor: its role in insulin resistance of obesity and diabetes. Diabetes 25: 1154-1163

3. Gavin J, Roth J, Neville D, De Meyts P, Buell D (1974) Insulin dependent regulation of insulin receptor concentrations. A rapid demonstration in cell culture. Proc Natl Acad Sci 71: 84-88

4. Roth J, Kahn C, Lesniak M, Borden P, De Meyts P, Megyesi K, Nevill D, Gavin J, Soll A, Freychet P, Goldfine I, Bass R, Archer J (1976) Receptor for insulin, NSILA-S, and growth hormone. Application to disease states in man. Recent Prog Horm Res 31: 95-139

5. Marshall S, Olefsky $\mathbf{J}$ (1980) Effects of insulin incubation on insulin binding, glucose transport, and insulin degradation by isolated rat adipocytes. Evidence of hormone-induced desensitization at the receptor and postreceptor level. J Clin Invest 66: 763-772

6. Stevens J, Atkinson R, Pohl S (1980) Insulin-induced insulin resistance of lipolysis in human adipocytes in organ culture. J Clin Endocrinol Metab 51:921-924

7. Kolterman O, Insel J, Saekow M, Olefsky J (1980) Mechanisms of insulin resistance in human obesity. Evidence for receptor and postreceptor defects. J Clin Invest 65: 1272-1284

8. Pedersen O, Hjollund E (1982) Insulin receptor binding to fat and blood cells and insulin action in fat cells from insulin-dependent diabetics. Diabetes 31: 706-715

9. Harrison L, King-Roach A (1976) Insulin sensitivity of adipose tissue in vitro and the response to exogenous insulin in obese human subjects. Metabolism 25: 1095-1101

10. Nagulesparan M, Savage $P$, Unger R, Bennett P (1979) A simplified method using somatostatin to assess in vivo insulin resistance over a range of obesity. Diabetes 28: 980-983

11. Amatruda J, Newmeyer M, Clang C (1982) Insulin-induced alterations in insulin binding and insulin action in primary cultures of rat hepatocytes. Diabetes 31: 145-148 
12. Kobayashi M, Olefsky J (1979) Effect of experimental hyperglycaemia on intracellular glucose metabolism of isolated adipocytes. Diabetologia 17:111-116

13. Doberne L, Greenfield M, Schulz B, Reaven G (1981) Enhanced glucose utilization during prolonged glucose clamp studies. Diabetes $30: 829-835$

14. Rizza R, Mandarino L, Gerich J (1981) Dose-response characteristics for effects of insulin on production and utilization of glucose in man. Am J Physiol E360-E634

15. Olefsky J (1976) Decreased insulin binding to adipocytes and circulating monocytes from obese subjects. J Clin Invest 57: $1165-1172$

16. DeBodo R, Steele R, Altszuler N, Dunn A, Bishop J (1963) On the hormone regulation of carbohydrate metabolism: studies with $\mathrm{C}^{14}$ glucose. Recent Prog Horm Res 19: 445-488

17. Boyum A (1968) A one-stage procedure for isolation of granulocytes and lymphocytes from human blood. Scand J Clin Lab Invest 21 (Suppl 97): 51-76

18. Yam L, Li C, Crosby W (1971) Cytochemical identification on monocytes and granulocytes. Am J Clin Pathol 55: 283-290

19. De Meyts P (1976) Insulin and growth hormone receptors in human cultured lymphocytes and peripheral blood monocytes. In: Blecker M (ed) Methods of receptor research. Dekker, New York. pp.301-383

20. Pedersen O, Hjollund E, Beck-Nielsen H, Linkskov H, Sonne O, Gleimann J (1981) Insulin receptor binding and receptor-mediated insulin degradation in human subjects. Diabetologia 20: 636-641

21. Rodbell M (1964) Metabolism of isolated fat cells. I. Effects of hormone on glucose metabolism and lipolysis. J Biol Chem 239: $375-380$

22. Hirsch J, Gallian E (1968) Methods for the determination of adipose cell size in man and animals. J Lipid Res 9: 110-119

23. Herbert V, Lau K, Gottlieb C, Bleicher S (1965) Coated charcoal immunoassay of insulin. J Clin Endocrinol Metab 25: 1375-1384

24. Kobayashi M, Olefsky J (1978) Effect of experimental hyperinsulinemia on insulin binding and glucose transport in isolated rat adipocytes. Am J Physiol 235: E53-E62

25. Martin C, Desai K, Steiner G (1983) Receptor and postreceptor insulin resistance induced by in vivo hyperinsulinemia. Can J Physiol Pharmacol 61: 802-807

26. Trimble E, Weir G, Gjinovci A, Assimacopoulos-Jeannet F, Benzi $R$, Renold A (1984) Increased insulin responsiveness in vivo and in vitro consequent to induced hyperinsulinemia in the rat. Diabetes 33: 444-449

27. Horton ES, Wardzala L, Hirshman M, Pofcher E, Horton ED (1983) Chronic hyperinsulinemia increases insulin binding and insulin-stimulated glucose transport and metabolism in the rat without altering insulin sensitivity. Diabetes $32: 25 \mathrm{~A}$

28. Bjorntorp P, Sjostrom (1978) Carbohydrate storage in man: speculation and some quantitative considerations. Metabolism 27: 1853-1865

29. Service F, Nelson R, Rubenstein A, Go V (1978) Direct effect of insulin on secretion of insulin, glucagon, gastric inhibitory polypeptide and gastrin during maintenance of normoglycaemia. $\mathrm{J}$ Clin Endocrinol Metab 47: 488-493

30. Insel J, Kolterman O, Saekow M, Olefsky J (1980) Short-term regulation of insulin receptor affinity in man. Diabetes 29: 132-139

31. Mott D, Howard B, Bennett P (1979) Stoichiometric binding and regulation of insulin receptors on human diploid fibroblasts using physiologic insulin levels. J Biol Chem 254: 8762-8767

32. Le Marchand-Brustel Y, Jeanrenaud B, Freychet P (1978) Insulin binding and effects in isolated soleus muscle of lean and obese mice. Am J Physiol 234: E348-E358

33. Bonen A, Tan M, Watson-Wright W (1981) Insulin binding and glucose uptake differences in rodent skeletal muscle. Diabetes 30 : $72-704$

34. Mandarino L, Baker B, Rizza R, Genest T, Gerich J (1984) Infusion of insulin impairs human adipocyte glucose metabolism in vitro without decreasing adipocyte insulin receptor binding. Diabetologia $27: 358-363$

35. Bar R, Gorden P, Roth J, Kan C, De Meyts P (1976) Fluctuations in the affinity and concentrations of insulin receptors on circulating monocytes of obese patients. Effects of starvation, refeeding and dieting. $\mathrm{J}$ Clin Invest 58: 1123-1135

Received: 14 May 1984

and in revised form: 16 November 1984

Robert A. Rizza

Mayo Clinic and Foundation

Department of Medicine

200 Southwest First Street

Rochester

Minnesota, 55905

USA 